\title{
Effect of Brefeldin A on the Development of Sargassum cymosum Zygotes (Phaeophyceae, Fucales): Structural and Ultrasctructural Analysis
}

\author{
Ticiane Rover ${ }^{1}$, Zenilda L. Bouzon ${ }^{2}$, Carmen Simioni ${ }^{3}$ \\ ${ }^{1}$ Plant Cell Biology Laboratory, Department of Cell Biology, Embryology and Genetics, Federal University of Santa Catarina, \\ Florianópolis, SC, Brazil \\ ${ }^{2}$ Central Laboratory of Electron Microscopy, Federal University of Santa Catarina, Florianópolis, SC, Brazil \\ ${ }^{3}$ Postdoctoral Research of Post Graduate Program in Cell Biology and Development, Department of Cell Biology, \\ Embryology and Genetics, Federal University of Santa Catarina, Florianópolis, SC, Brazil \\ Email: *tici_bio@hotmail.com
}

How to cite this paper: Rover, T., Bouzon, Z.L. and Simioni, C. (2020) Effect of Brefeldin A on the Development of Sargassum cymosum Zygotes (Phaeophyceae, Fucales): Structural and Ultrasctructural Analysis. American Journal of Plant Sciences, 11, 245-261.

https://doi.org/10.4236/ajps.2020.112019

Received: July 24, 2019

Accepted: February 25, 2020

Published: February 28, 2020

Copyright ( 2020 by author(s) and Scientific Research Publishing Inc. This work is licensed under the Creative Commons Attribution International License (CC BY 4.0).

http://creativecommons.org/licenses/by/4.0/

\section{(c) (i) Open Access}

\begin{abstract}
To evaluate the effects of brefeldin A (BFA) on Golgi bodies and indirectly on the polarized development of $S$. cymosum zygotes, zygotes were cultured at concentrations of $4 \mu \mathrm{M}, 8 \mu \mathrm{M}, 16 \mu \mathrm{M}$ and $32 \mu \mathrm{M}$ of BFA, prepared in sterilized seawater. After 12 hours, the samples were fixed and processed for transmission electron microscopy (TEM), confocal laser scanning microscopy, light microscopy and cell counting. For recovery analysis, after treatment, the samples were again placed in sterile seawater for over 12 hours. In the control, after 12 hours, the embryos were adhered and with advanced stage of development, presenting up to 6 cell divisions. In the treated samples, the embryos did not adhere and only in the lower concentrations were they visualized with cellular divisions, is that in the highest concentration, the majority of the zygotes were dead. After recovery, embryos showed development only in the lowest concentrations. By confocal microscopy, the treated samples had an irregular distribution of chloroplasts and physodes. Also through TEM, it was possible to observe the loss of organization of Golgi bodies, in turn leading to the formation of vesicles and fusion of physodes. We can conclude that Golgi bodies are responsible for the production and secretion of molecules related to the adhesion and formation of cell wall membrane, also aiding in the polarization and orientation of physodes. The fused physodes occupied much of the cytoplasm, preventing other cytoplasmic processes, thus directly affecting the development of this alga.
\end{abstract}




\section{Keywords}

Transmission Electron Microscopy, Confocal Laser Scanning Microscopy, Golgi Bodies, Polarization, Physodes

\section{Introduction}

The genus Sargassum is a conspicuous component of the benthic marine flora that populates the tropical and temperate oceans of the world [1] [2]. It is often considered the most important algae in abundance in the environment [3]. Representatives of this genus have oogamous reproduction, and it is often the only form of reproduction [1]. Zygotes formed after fertilization remain attached to the receptacle by mucilage until they reach a more advanced stage of cell division [4] [5].

At this stage, development depends on asymmetric cell division, similar to other organisms, including fungi [6], animals [7] and plants [8] [9]. Studies describing the role of the endomembrane system in developing fucoid algae, such as Fucus and Silvetia, were performed, especially those of Belanger and Quatrano [10], Kropf et al. [11], Fowler [12] and Brownlee et al. [13].

Fucus is representative of polarized development where the oosphere is initially symmetrical, but at the time of fertilization, the zygote becomes asymmetrical, forming two growing ends, an apical pole and a rhyzoidal pole [14]. The rhizoidal pole is characterized by a network of highly dynamic cortical actin that rapidly repositions by depolymerization/repolymerization during alignment of the new growth axis [14] [15]. During the polarization and development, the endomembrane system accumulates preferentially at the rhizoidal pole, acting in conjunction with the actin network [10].

In addition, asymmetric cell growth and stabilization of the polar axis require a secretion originating from the rhizoidal pole [16]. Berger et al. [17] reported that differences in extracellular matrix between the rhizoid and thallus result from asymmetric secretion and appear to influence the determination of the formation of rhyzoids. The secretory activity in a developing cell requires the recycling of material deposited on the plasma membrane. Endocytosis has been documented for some time as the main mechanism for recycling the membrane in many cell types in eukaryotes [18]. When this deposition of secretory membrane ends, it is necessary to maintain contact with the surface area in growth ends to maintain correct cell elongation [10]. The trans-Golgi network (TGN) was defined as a specialized compartment on the trans-side of the Golgi that is responsible for delivering proteins to the plasma membrane, lysosomes, and extracellular space from the Golgi. Live cell imaging has revealed that the TGN acts not only in the secretory pathway, but also in the endocytic pathway in plant cells [19].

The plant Golgi is nevertheless a fascinating organelle that has unique fea- 
tures, especially when compared with its mammalian counterpart, it is polydisperse rather than being present as a continuous perinuclear ribbon, it does not disassemble during mitosis, and it is motile [20]. These characteristics are of great importance, especially because Golgi stacks in plants, along with their protein processing functions, have been termed polysaccharide factories and their activity is essential for formation of a cell wall during cytokinesis and growth.

Golgi bodies are highly concentrated at specific sites in the cell wall growth poles [21]. Vesicles derived from this organelle containing the material to form the cell wall are directed and concentrated in the growing ends, giving evidence of the central role of Golgi bodies by their synthesis of these materials [22].

To demonstrate the development of the polarized endomembrane system by secretion of localized adhesive components and cell wall, studies have used the antibiotic lipophilic fungal brefeldin A (BFA). BFA may block the mechanisms of vesicle movement in plants [23], the secretion polysaccharides, and cell wall proteins [24] [25]. In inhibition of secretion, Nebenfuhr et al. [26] describe that the molecular target for BFA appears to be the same in all eukaryotic cells, a Sec7-type GTP exchange factor (GEF), that is necessary for activation of Arflp. Its best-studied immediate effects are the inability to recruit COPI coat proteins onto Golgi membranes. In the endocytic pathway, constitutive cycling of plasmatic membranes (PM) proteins shows to be blocked by BFA [27] [28]. Second, Richter et al. [28]most PM proteins undergo constitutive cycling between the PM and some endosomal compartment(s), but there appear to be more than one recycling pathway from endosomes to the plasmatic membranes. Continued inhibition of basal recycling by BFA results not just in BFA compartments but in apical localization of auxin efflux carrier PIN1.

In brown algae, this inhibitor was used to directly examine the effect of the endomembrane system on polarization development in zygotes of Silvetia [25]. In red algae, BFA affected the structure of Golgi bodies, inhibiting the secretory vesicles that form germ tube development in the tetraspores from Gelidium floridanum [29]. In green algae, it inhibited adhesion of the zoospores of Enteromorpha [23].

Thus, the present study aimed to evaluate the effects of different concentrations of BFA on Golgi bodies, either directly or indirectly, relative to polarization development in $S$. cymosum zygotes.

\section{Material and Methods}

\subsection{Algal Material}

Fertile plants of $S$. cymosum C. Agardh were collected at low tide at Ponta das Canas-Ilha de Santa Catarina, $\left(27^{\circ} 29^{\prime} 18.8^{\prime \prime S}\right.$ and $\left.48^{\circ} 32^{\prime} 12.9^{\prime \prime} \mathrm{W}\right)$, Florianopolis, Santa Catarina, in January and February 2014, during the summer season. The algal samples were collected from the rocky shore and transported at ambient temperature in dark containers to LABCEV-UFSC (Plant Cell Laboratory, Federal University of Santa Catarina, Florianopolis, Santa Catarina, Brazil). To 
eliminate macroepiphytes, the collected algae were meticulously cleaned with a brush and filtered seawater.

\subsection{Culture Conditions}

In the laboratory, the fertile branches, characterized by the presence of gametes in receptacles, were separated from receptacles. These branches were placed in Beakers $(200 \mathrm{~mL})$, with strong aeration, to induce the release of gametes. Receptacles were potentiated by placing them in uniform light $\left(45 \mu \mathrm{mol} \cdot \mathrm{m}^{-2} \cdot \mathrm{s}^{-1}\right)$ at $22^{\circ} \mathrm{C}(+/-1)$ in sterile seawater for 12 hours and then transferred to dark for $12 \mathrm{~h}$ [30]. After fecundation, zygotes were cultivated on slides in Petri dishes under the same conditions described. All analyses were performed 12 hours post-fertilization (hpf).

\subsection{Treatment with Brefeldin A (BFA)}

Stock solution of fungal macrocyclic lactone brefeldin A (BFA) (B-7651 Sigma Chemicals, Germany) was prepared at the concentration of $5 \mathrm{mM}$ in dimethyl sulfoxide (DMSO, Merck, Darmstadt, FRG). From this stock solution, four (4) final treatment concentrations $(4 \mu \mathrm{M}, 8 \mu \mathrm{M}, 16 \mu \mathrm{M}$ and $32 \mu \mathrm{M})$ were prepared in sterilized seawater. To perform the experimental treatments, one control without BFA was cultivated with sterilized seawater containing DMSO, while the BFA treatment concentrations were added individually after the formation of zygotes, following Simioni et al. [29] with modifications. Four replicates were made for each experimental group. After treatment (12 hours), the samples were fixed and processed for transmission electron microscopy, confocal laser scanning microscopy, light microscopy and cell counting.

For recovery analysis, after treatment, the samples were again placed in sterile seawater for over 12 hours in order to observe the recovery capacity of the cells after treatment with BFA, followed by analysis under light microscopy.

\subsection{Analysis of Morphology and Development Process}

Samples of zygotes and embryos of $S$. cymosum, both control and treatment, were fixed in paraformaldehyde solution with $2.5 \%$ sodium phosphate buffer 0.1 M. They were photographed to analyze general morphology, as well as perform cell counting. The morphological characteristics of control and treated samples were investigated and photographed with an epifluorescent Olympus BX $41 \mathrm{mi}$ croscope equipped with Image Q Capture Pro 5.1 software. The analysis was performed by evaluating the following characteristics: 1) zygotes without division; 2) zygotes with a division; 3) zygotes with $2-6$ divisions; 4) zygotes with more than 6 divisions and 5) dead zygotes. Morphological characteristics were measured on 300 zygotes per slide for the different treatments. Four replicates were made for each experimental group.

Data were submitted analysis of variance (ANOVA) and the Tukey a posteriori test. All statistical analyses were performed with Statistic, version 10.0, considering significance at $p \leq 0.05$. 


\subsection{Confocal Laser Scanning Microscopy (CLSM)}

Zygotes and embryos of $S$. cymosum were analyzed "in vivo" using a Leica DMI6000 B confocal microscope. Phenolic compounds were submitted to laser excitation wavelength of $405 \mathrm{~nm}$ and an emission spectrum of $510 \mathrm{~nm}$ to 600 $\mathrm{nm}$. The autofluorescence of chloroplasts was excited with laser wavelength of $488 \mathrm{~nm}$ and emission spectrum of $600 \mathrm{~nm}$ to $700 \mathrm{~nm}$ [31]. The phenolic compounds and chloroplasts were analyzed separately to better identify them.

\subsection{Transmission Electron Microscopy (TEM)}

The samples were fixed in 2.5\% glutaraldehyde, $2.0 \%$ paraformaldehyde, $5 \mathrm{mM}$ $\mathrm{CaCl}_{2}$, and $75 \mathrm{mM}$ sodium cacodylate buffer at $\mathrm{pH} 7.2$ from 8 to 12 hours at $4^{\circ} \mathrm{C}$. After fixation, the material was rinsed three times, 30 minutes each, in the same buffer. This was followed by a post-fixation in $2.0 \%$ osmium tetroxide and $5 \mathrm{mM}$ $\mathrm{CaCl}_{2}$ in $75 \mathrm{mM}$ sodium cacodylate buffer for 4 hours at room temperature. Then rinses were performed in the same buffer, followed by dehydration in increasing series of acetone (30 minutes each). Specimens were then infiltrated in graded series of acetone and Spurr's resin for 3 days, followed by two infiltrations in pure resin (12 hours each) and polymerization in an oven at $70^{\circ} \mathrm{C}$ for 24 hours. The ultrathin sections were contrasted with $1 \%$ uranyl acetate and $1 \%$ lead citrate [32]. Subsequently, the sections were observed and photographed in JEM 2100 transmission electron microscope provided by the Microscopy Center of the Federal University of Santa Catarina. The analysis by TEM aimed to comparatively analyze the behavior of cellular organelles during different stages of maturation of $S$. cymosum embryos.

\section{Results}

\subsection{Analysis of Morphology and Development}

The treatments showed significant differences in the number of cell divisions and mortality rate (Table 1 and Table 2 ) for both the zygotes at $12 \mathrm{hpf}$, as well as for those maintained in recovery for $24 \mathrm{hpf}$.

In the control samples at $12 \mathrm{hpf}$ (Figure 1(a), Table 1), the embryos were adherent and presented a lighter coloration, evidencing a homogeneous distribution of physodes, most of which exhibit polarization at an advanced stage of more than 6 cell divisions (49\%). Embryos were also observed to have 2 to 6 divisions (35\%), a lower percentage with only one division (8.33\%) or no division at all (7.59\%). In the control, after 12 hours, none of the embryos was dead. Control embryos at $24 \mathrm{hpf}$ (Figure 1(b), Table 2) 4 exhibit the same color, but $83.44 \%$ already showed over 6 cell divisions, and at this stage, no embryo was dead or in the early stages, i.e., with no division or only 1 division.

For BFA treatment at $4 \mu \mathrm{M}$ (Figure 1 (c), Table 1), zygotes at $12 \mathrm{hpf}$ were seen to be mostly adherent with a more dense coloration and some physodes grouped in centralized regions of cells. These embryos were at the initial stage of polarization, having $38.33 \%$ with no division, $5.66 \%$ with only one division, 
Table 1. Counting of zygotes and embryos of the $S$. cymosum after 12 hours of treatment with different concentrations of BFA. (Mean \pm SD). Different letters indicate significant differences according to the Tukey test $(p \leq 0.05)(\mathrm{n}=900)$.

\begin{tabular}{cccccc}
\hline & Without division & 1 division & $2-6$ division & +6 division & Dead \\
\hline Control & $22.77 \pm 2.05 \mathrm{~d}$ & $25.00 \pm 1.63 \mathrm{c}$ & $105.33 \pm 3.40 \mathrm{a}$ & $147.00 \pm 6.16 \mathrm{a}$ & $0.00 \pm 0.00 \mathrm{~d}$ \\
$\mathbf{4} \mu \mathrm{M}$ & $115.00 \pm 3.56 \mathrm{c}$ & $17.00 \pm 1.63 \mathrm{~d}$ & $82.00 \pm 1.63 \mathrm{~b}$ & $78.00 \pm 1.63 \mathrm{~b}$ & $8.00 \pm 2.16 \mathrm{c}$ \\
$\mathbf{8} \mu \mathrm{M}$ & $156.67 \pm 2.49 \mathrm{~b}$ & $83.00 \pm 2.16 \mathrm{e}$ & $43.00 \pm 0.82 \mathrm{c}$ & $4.00 \pm 0.82 \mathrm{c}$ & $13.33 \pm 1.70 \mathrm{c}$ \\
$\mathbf{1 6} \mu \mathrm{M}$ & $176.00 \pm 3.27 \mathrm{a}$ & $51.67 \pm 1.25 \mathrm{~b}$ & $32.67 \pm 2.05 \mathrm{~d}$ & $0.00 \pm 0.00 \mathrm{c}$ & $39.67 \pm 0.47 \mathrm{~b}$ \\
$\mathbf{3 2} \mu \mathrm{M}$ & $16.00 \pm 0.82 \mathrm{~d}$ & $10.67 \pm 0.94 \mathrm{e}$ & $15.00 \pm 1.41 \mathrm{e}$ & $0.00 \pm 0.00 \mathrm{c}$ & $258.33 \pm 2.49 \mathrm{a}$
\end{tabular}

Table 2. Counting of zygotes and embryos of the $S$. cymosum after 24 hours, 12 hours of BFA treatment followed by another 12 hours of recovery in sterile water sea. (Mean \pm $\mathrm{SD}$ ). Different letters indicate significant differences according to the Tukey test ( $p \leq$ $0.05)(\mathrm{n}=900)$.

\begin{tabular}{cccccc}
\hline & Without division & 1 division & $2-6$ division & +6 division & Dead \\
\hline Controle & $0.00 \pm 0.00 \mathrm{c}$ & $0.00 \pm 0.00 \mathrm{c}$ & $49.67 \pm 5.73 \mathrm{c}$ & $250.33 \pm 5.73 \mathrm{a}$ & $0.00 \pm 0.00 \mathrm{e}$ \\
$\mathbf{4} \mu \mathrm{M}$ & $60.33 \pm 2.87 \mathrm{~b}$ & $18.00 \pm 0.82 \mathrm{~b}$ & $59.00 \pm 0.82 \mathrm{~b}$ & $131.33 \pm 1.25 \mathrm{~b}$ & $31.33 \pm 2.49 \mathrm{c}$ \\
$\mathbf{8} \mu \mathrm{M}$ & $153.33 \pm 2.49 \mathrm{a}$ & $15.00 \pm 0.82 \mathrm{~b}$ & $93.00 \pm 0.82 \mathrm{a}$ & $19.00 \pm 0.82 \mathrm{~d}$ & $19.67 \pm 2.05 \mathrm{~d}$ \\
$\mathbf{1 6} \mu \mathrm{M}$ & $63.33 \pm 2.49 \mathrm{~b}$ & $41.00 \pm 2.16 \mathrm{a}$ & $52.67 \pm 1.70 \mathrm{bc}$ & $91.00 \pm 2.94 \mathrm{c}$ & $52.00 \pm 2.16 \mathrm{~b}$ \\
$\mathbf{3 2} \mu \mathrm{M}$ & $62.33 \pm 5.44 \mathrm{~b}$ & $0.00 \pm 0.00 \mathrm{c}$ & $0.00 \pm 0.01 \mathrm{e}$ & $0.00 \pm 0.02 \mathrm{e}$ & $237.67 \pm 5.44 \mathrm{a}$ \\
\hline
\end{tabular}



Figure 1. Light Microscopy of Sargassum cymosum zygote. (a), (c), (e), (g), (i): Samples treated with different concentrations of Brefeldin A (BFA). (b), (d), (f), (h), (j): Samples placed in recovery for another 12 hours (total 24 hours hpf) in sterile water sea, without the addition of BFA. Scales: $20 \mu \mathrm{m}$. 
$27.33 \%$ from 2 to 6 divisions, and only $26 \%$ over 6 divisions. Different from control, the treatment groups showed $2.66 \%$ dead embryos. At that same treatment concentration, samples in recovery for an additional 12 hours, or $24 \mathrm{hpf}$ (Figure 1(d), Table 2) exhibited a greater number of cell divisions with polarization and lighter coloration. While $20.11 \%$ of the embryos were still without any division at $24 \mathrm{hpf}, 43.66 \%$ presented polarization at an advanced stage with more than 6 cell divisions presenting recover ability. At that stage, $10.33 \%$ of the embryos were dead.

When treated with BFA $8 \mu \mathrm{M}$ (Figure $1(\mathrm{e})$, Table 1), samples at $12 \mathrm{hpf}$ presented nonadherent embryos with denser coloration, and most had no cell division (52\%) or only one division (27.66\%), with a higher mortality rate compared to treatment with $4 \mu \mathrm{M}(4.44 \%)$. Samples placed in recovery (Figure 1(f), Table 2) showed dense punctuations inside, indicating the presence of physodes grouped in the cytoplasm. At this stage, $51.11 \%$ of zygotes had no cell division, and only $31 \%$ of zygotes exhibited 2 to 6 cell divisions.

In BFA treatment $16 \mu \mathrm{M}$ (Figure 1 (g), Table 1 ), zygotes at $12 \mathrm{hpf}$ were nonadherent and, in most cases, showed no polarization or cell division (58.66\%), while $17.22 \%$ had 1 cell division and $10.89 \%$ from 2 to 6 divisions. These embryos presented the same characteristics as the previous treatment with presence of dense regions indicating groups of physodes (Figure $1(\mathrm{~g})$ ). Mortality was $13.22 \%$. Even after recovery (Figure $1(\mathrm{~h})$, Table 2 ), the number of dead embryos increased by $17.33 \%$; however, upon recovery, polarization was evident with the presence of about $13.66 \%$ of the embryos with 1 division, $17.55 \%$ from 2 to 6 divisions, and $30.33 \%$ with more than 6 cell divisions.

For BFA treatment with $32 \mu \mathrm{M}$ (Figure 1(i), Figure 1(j), Table 1), zygotes at $12 \mathrm{hpf}$ and zygotes in recovery $24 \mathrm{hpf}$ both showed a large amount of dead embryos ( $86.11 \%$ and $79.22 \%$, respectively), characterized by noncellular polarization, and highly grouped physodes occupying much of the cytoplasm. We saw no adhesion to substrate with this treatment.

\subsection{Observation under Confocal Laser Scanning Microscopy}

Control zygotes of $S$. cymosum at $12 \mathrm{hpf}$ showed polarization, and a homogeneous distribution of chloroplasts and physodes (Figures 2(a)-(c)).

BFA $4 \mu \mathrm{M}$ showed an irregular distribution of physodes and chloroplasts in the cytoplasm (Figures 2(d)-(f)), showing regions with groupings of physodes or chloroplasts (Figure 2(f)). BFA $8 \mu \mathrm{M}$ and $16 \mu \mathrm{M}$ showed heterogeneous distribution of chloroplasts and physodes and exhibited retraction in the cytoplasm, altering the general morphology of the zygote (Figures 2(g)-(i)). For treatment of zygotes with BFA $32 \mu \mathrm{M}$, both physodes and chloroplasts showed behavior similar to that with $4 \mu \mathrm{M}$ treatment, but with larger groupings of physodes and chloroplasts (Figures 2(j)-(o)).

\subsection{Observation under Transmission Electron Microscopy}

Control zygotes of $S$. cymosum analyzed under transmission electron microscopy 


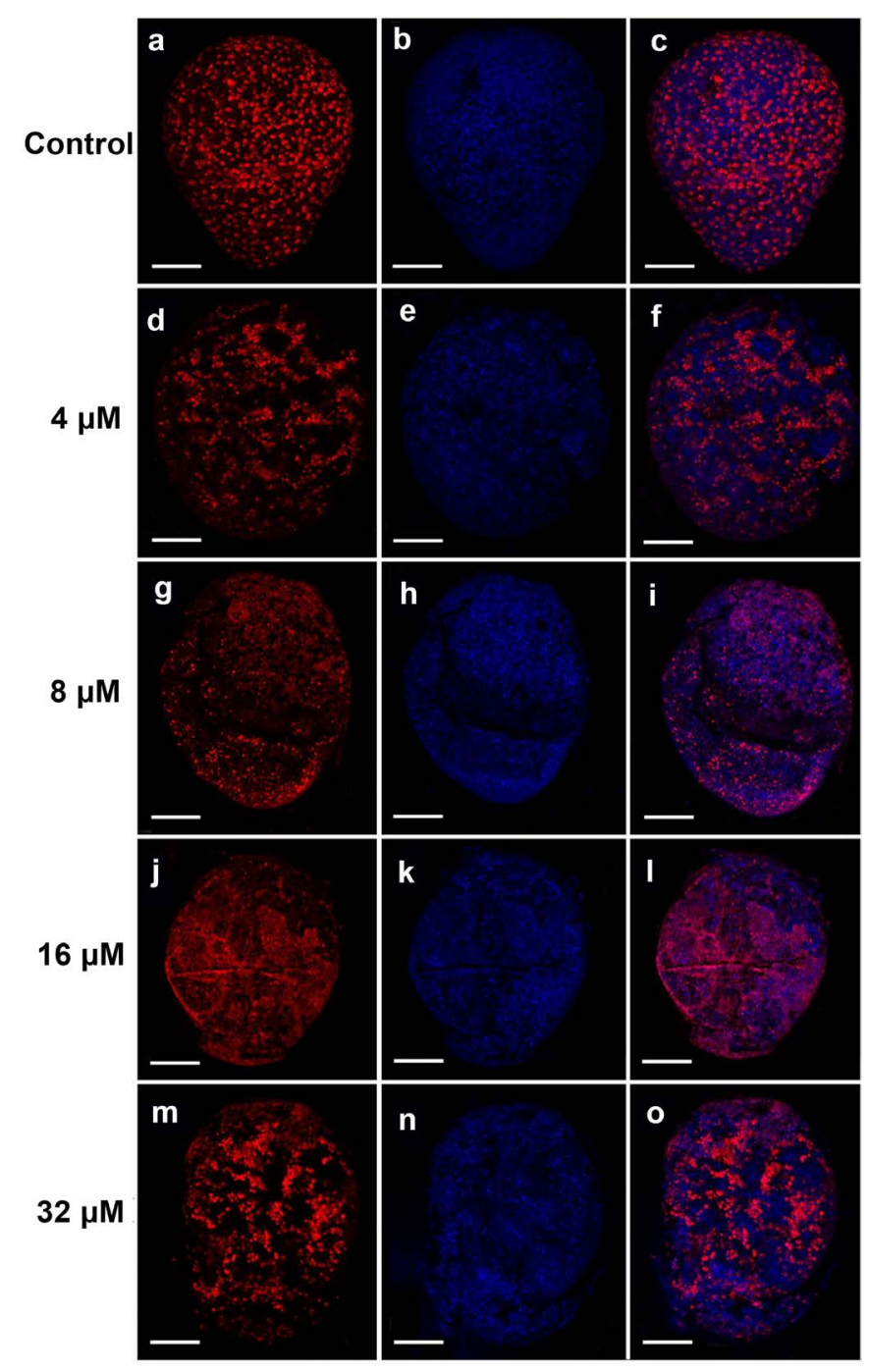

Figure 2. Confocal microscopy of Sargassum cymosum zygotes after 12 hours of treatment with BFA. (a)-(o): the autofluorescence of chloroplasts in red and autofluorescence of phenolic compounds (physodes) in blue. (a)-(c): control samples. (d)-(f): samples treated with BFA $4 \mu \mathrm{M}$. (g)-(i): samples treated with BFA 8 $\mu \mathrm{M}$. (j)-(l): samples treated with BFA $16 \mu \mathrm{M}$. (m)-(o): samples treated with BFA $32 \mu \mathrm{M}$. Scales: $40 \mu \mathrm{M}$.

(TEM) showed cytoplasm with a large number of electron-transparent vesicles interspersed with dense regions of organelles with electron-dense vesicles with phenolic compounds and physodes (Figure 3(a)). The thick cell wall showed two well-defined regions, the outer narrow region had a higher compaction of cellulose fibers, while the inner region was less dense (Figure 3(b)). Observation of organelle clusters revealed small, circular chloroplasts in the early stage of development (Figure $3(\mathrm{c})$ ). In this region, we also observed the presence of physodes surrounded membrane (Figure 3(d)) and a large number of hypertrophic Golgi bodies (Figure 3(e)-(f)), often with 4 to 6 cisternae and many vesicles around them (Figure $4(\mathrm{f})$ ). 



Figure 3. Electron microscopy of control zygote of the Sargassum cymosum. (a) Overview with the presence of cytoplasm with vesicles and regions with high density of organelles. (b) Detail of the cell wall (CW). (c) Detail of chloroplast organization (C). (d) Detail of physodes (P). (e) Presence of large amounts of Golgi bodies $(\mathrm{G})$, especially near the division region (arrow). (f) Detail of a Golgi body and its cisternae. Vesicles (V). Mitochondria (M).

Samples treated with BFA $4 \mu \mathrm{M}$ exhibited typical ultrastructural alterations compared to control (Figures 4(a)-(d)). Cell wall thickness decreased (Figure 4(a), Figure 4(b)). In the cytoplasm, changes were observed in Golgi bodies, some with a smaller number of cisternae, but some newly forming vesicles (Figure 4(a), Figure 4(d)), but others totally degraded (Figure 4(b)). Similar to control, the pattern of electron-dense vesicles of physodes was no longer seen to be dispersed irregularly (Figure 4(c)). Organelles such as chloroplasts presented dilatations between the thylakoid membranes (Figure 4(c)) and the presence of numerous electron-transparent vesicles (Figure 4(d)).

When submitted to treatment with $8 \mu \mathrm{M}$, the cytoplasm of zygotes showed many vesicles and physodes aggregates (Figure $5(\mathrm{a})$ ). These physodes presented as degraded and dispersed among other cytoplasmic components without the formation of the standard electron-dense vesicles observed in controls or the 

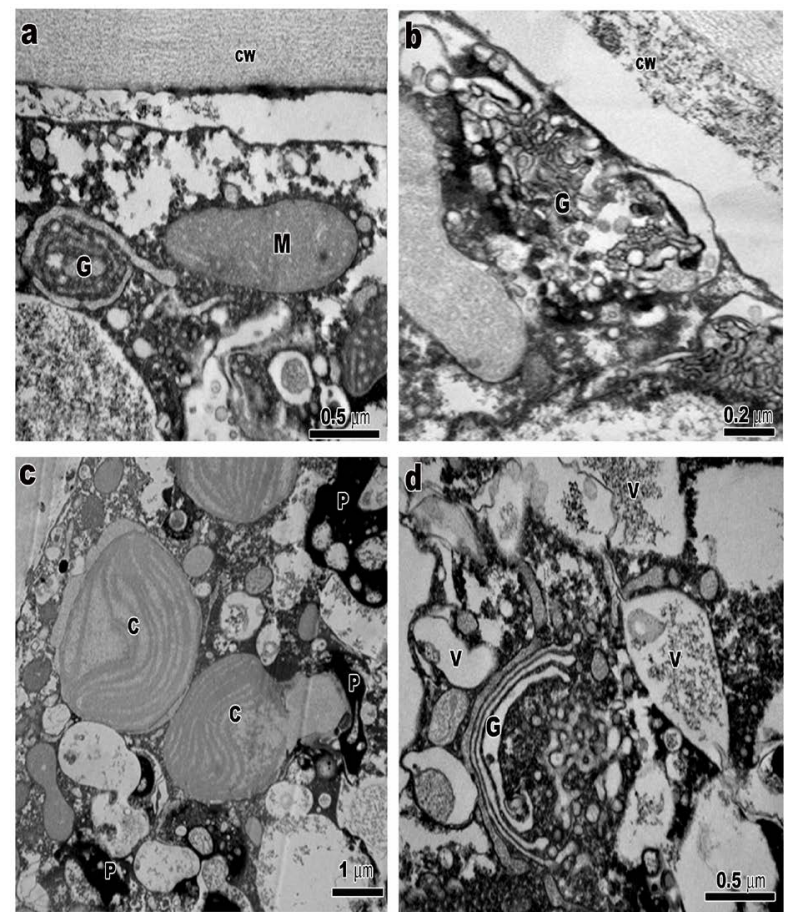

Figure 4. Electron Microscopy of Sargassum cymosum zygote treated with $4 \mu \mathrm{M}$ of Brefeldin A. (a) (b) Decreased cell wall thickness (CW) and the presence of Golgi bodies (G) with few cisternae (a) or degraded (b); (c) Detail of a chloroplast (C) with dilatations between the thylakoids. (d) Detail of the cytoplasm with the presence of a Golgi body with large amounts of vesicles (V). Mitochondria (M).

presence of electron-transparent vesicles inside (Figure 5(b)). However, this treatment presented an extremely low number of Golgi bodies (Figure 5(c), Figure 5(d)), a few cisternae with irregular shape (Figure 5(c)) and other Golgi with cisternae dispersed in cytoplasm (Figure 5(d)).

In some samples treated with BFA $16 \mu \mathrm{M}$ (Figure 6(a)), some physodes in the cytoplasm of zygotes were degraded, whereas others were fused and occupied larger areas centralized in the cytoplasm (Figure 6(b), Figure 6(c)). However, when compared to prior treatment, the samples exhibited few Golgi bodies with fewer cisternae dispersed in the cytoplasm (Figure 6(d)).

On the other hand, in the $S$. cymosum zygote treated with $32 \mu \mathrm{M}$ BFA, we observed a large amount of electron-transparent vesicles in the periphery of cytoplasm and phenolic compounds predominantly in the central region of physodes (Figures 7(a)-(c)). The physodes were clumped and/or merged into large vesicles in the central region, with the presence of large amount of unorganized membranes on the edge of physodes (Figure 7(d), Figure 7(e)).

\section{Discussion}

During the early development of $S$. cymosum, the zygote remains symmetrical, becoming asymmetric only at $4 \mathrm{hpf}$. When treated with different concentrations 

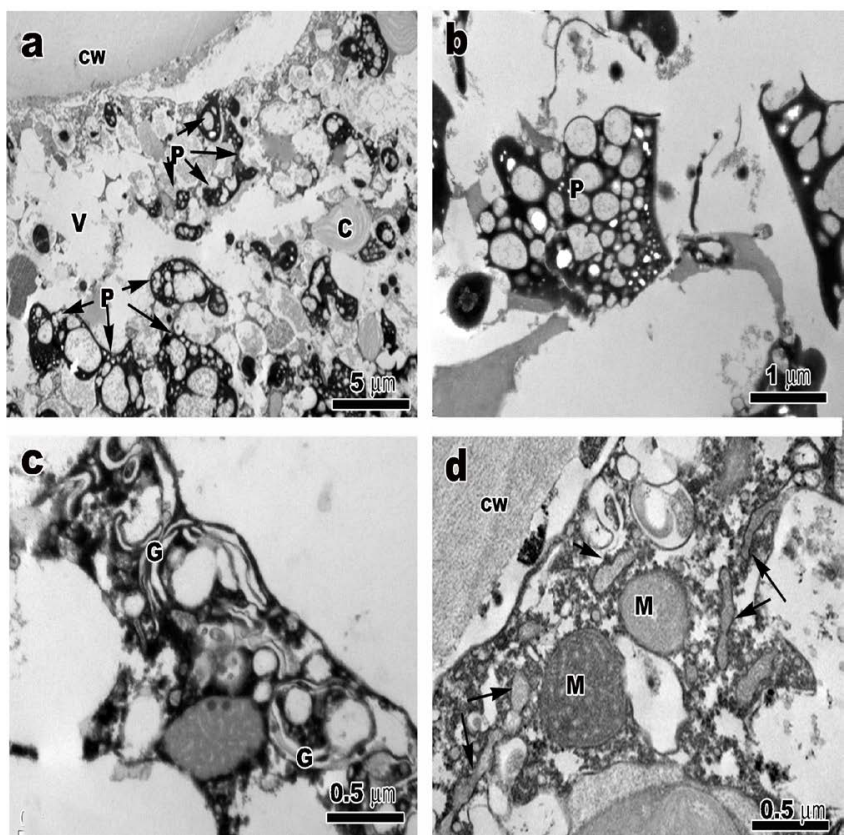

Figure 5. Electron Microscopy of Sargassum cymosum zygote treated with $8 \mathrm{mM}$ of Brefeldin A. (a) Overview highlighting a greater amount of physodes (P) distributed in an irregular manner throughout the cytoplasm. (b) Detail of a region with physodes with the presence of electron-transparent vesicles $(\mathrm{V})$ inside. (c) and (d) Detail of Golgi bodies (L), which have fewer cisternae (c) or just cisternae dispersed in the cytoplasm (arrowheads) (d) Mitochondria.
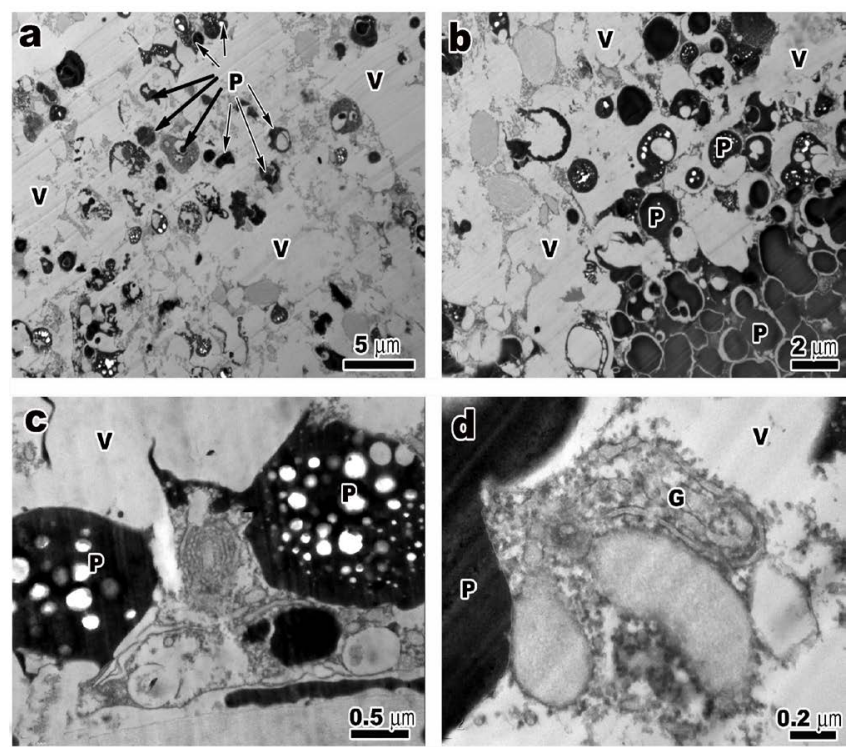

Figure 6. Electron Microscopy of Sargassum cymosum zygote treated with $16 \mu \mathrm{M}$ of Brefeldin A. (a) Cytoplasm of the region with the presence of physodes $(\mathrm{P})$ and a large amount of degraded vesicles (V). (b) Cytoplasmic region with fused physodes. (c) Detail of physodes. (d) Detail of the Golgi bodies (L) having few cisternae. 

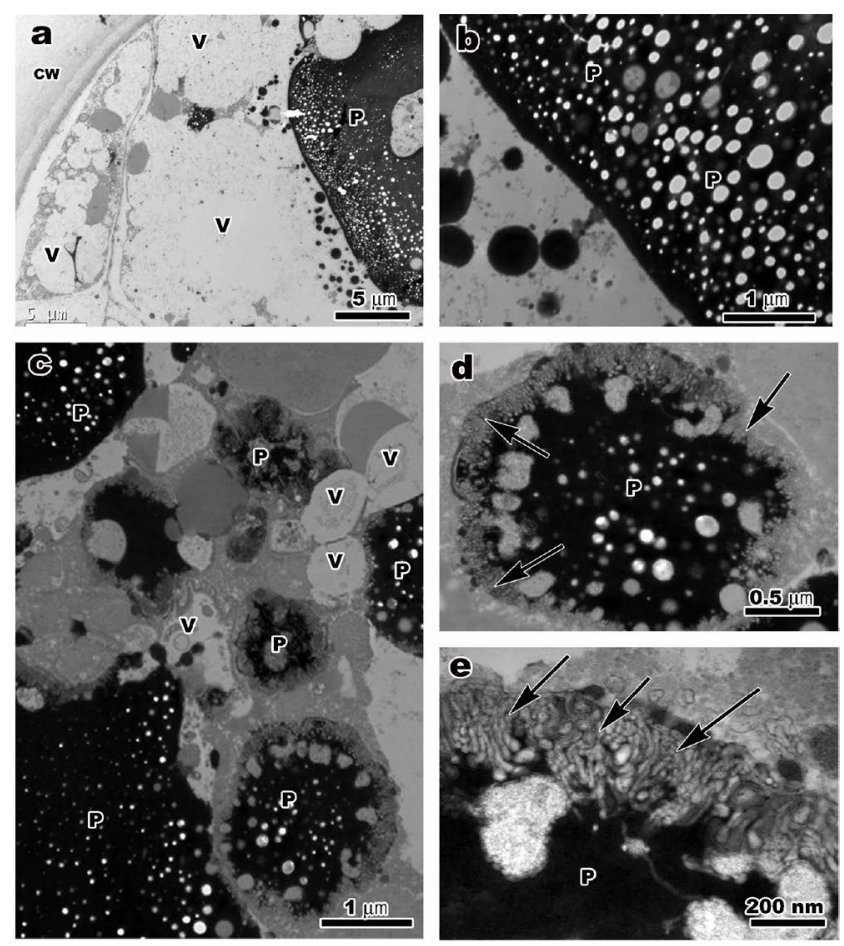

Figure 7. Electron Microscopy of Sargassum cymosum zygote treated with $32 \mu \mathrm{M}$ of Brefeldin A. (a) Overview of the cytoplasm highlighting the presence of vesicles $(\mathrm{V})$ in the peripheral region and a large amount of fused physodes $(\mathrm{P})$ in the central region. (b) and (c) Detailed grouping of physodes (d) and (e) Detail of the presence of large amounts of unorganized membranes (arrows) on the edge of physodes (arrows). Cell Wall (CW).

of BFA for 12 hours, changes in symmetry became evident, as well as cell division period, ultrastructural organization and distribution of phenolic compounds.

First, treatment with BFA prevented cell adhesion to the substrate, but did not prevent cell division at this stage of development. For Silvetia [33], Fucus [10] and tetraspores from Gelidium floridanum [29] [32], development and germination of tetraspores were dependent on adhesion to the substrate, which was significantly affected by treatment with BFA. For Sargassum vachellianum Greville [34], all of initial zygote development in the Sargassum genus adhere to the receptacle by a mucilage released together with the oospheres. Fucus and Silvetia zygotes at 2 to $3 \mathrm{hpf}$ already begin to secrete a mucilage composed of highly adhesive polysaccharides and phenolic compounds [35], which commences the process of fixation and polarity [33].

In this study, developmental delay in zygotes in relation to cell division was observed after BFA treatment and may be related to the difficulty of orienting the vesicles to the materials needed for the formation of new cell walls that will internally divide the zygote because of the changes observed Golgi bodies. The cytoplasm of the cells, the rhizoidal pole, is rich in Golgi vesicles, which deposit the contents inside the newly formed cell wall by exocytosis [36]. 
A polarized endomembrane system allows local deposition of membrane and cell wall precursors required for elongation and support, in addition to facilitating the formation of distinct apical and subapical areas at the extremities [37]. Based on changes in the Golgi visualized after BFA treatment, cell wall formation was indirectly inhibited. According to Tsekos [24], precursor structures of the enzymatic complex, the tetrahedral membranes, which are responsible for cell wall formation, were observed in the membranes of the Golgi cisternae near the face trans.

Golgi bodies in $S$. cymosum zygotes were affected by BFA, especially in treatments of $8 \mu \mathrm{M}, 16 \mu \mathrm{M}$ and $32 \mu \mathrm{M}$, with a decrease in the number of cisternae and an increase in the number of vesicles. In tetraspores of the G. floridanum, high vesicle formation was observed after BFA treatment [29]. These results are similar to those found in culture of embryonic plant cells, which also showed changes in the structure of the Golgi bodies and endoplasmic reticulum (ER) [38]. According to Henderson et al. [39], treatment with BFA affects the entire process of vesicle production which occurs as a result of inhibition of transport proteins of the ER to Golgi bodies and also influences a reduction in the number of cisternae [23] [24].

BFA blocks signaling proteins necessary for the formation and direction of the vesicles. The main targets of BFA treatment are the guanine nucleotide exchange factors (GEFs) (i.e. GEF proteins), which are involved in the activation of the ADP-ribosylation factor (ARF) family of proteins. According to Donaldson et al. [40] [41], BFA interacts with the ARFs of GTP-binding proteins in order to avoid catalysis of GTP to guanosine diphosphate (GDP). As a result, the coating required for nascent vesicles cannot be formed. Using both BFA and BFA analogues in Tobacco and Arabidopsis plants, Langhans et al. [42] demonstrated that the site of ARF-GEFs influences the pattern of morphological responses after adding BFA.

The principal effect of this study, generated as a result of changes caused by BFA in the bodies of Golgi was the increased and the fusion of physoids, the vesicles containing phenolic compounds. According to Schoenwelder [43], Golgi bodies and ER are responsible for the formation of physodes, and after treatment with BFA, physodes in zygotes of Phyllospora comosa the physoids were seen to accumulate mass, thus confirming our study, since BFA treatment as accompanied by an increase in fusion and accumulation of these vesicles containing phenolic compounds.

Low concentrations of BFA ( $8 \mu \mathrm{M}$ and $4 \mu \mathrm{M})$ allowed a slight cell polarization, but affected the timing of cell division, thus retarding development. However, these cells remained viable because when placed in water for recovery with sterile seawater, many zygotes exhibited continued development. Shaw and Quatrano [16] and Belanger and Quatrano [10] found that cytokinesis in Fucus zygotes was not prevented, even though BFA inhibited vesicle secretion. According to Bisgrove and Kropf [44], attachment of polar axis growth initiates a set of changes, especially ultrastructural, which will govern all cell divisions to main- 
tain correct development and fix the growth axis needed for the secretion of compounds specific for adhesion and cell wall, especially in the growth region of rhyzoids.

Higher concentrations of BFA ( $16 \mu \mathrm{M}$ and $32 \mu \mathrm{M})$ were the most lethal to zygotes analyzed, affecting cell division so that zygotes lacked symmetry or typical ultrastructural organization during this phase of development and not allowing zygotes to recover after treatment. Similar concentrations of BFA used in Fucus [16] and Pelvetia [35] completely inhibited the polarization of these algae.

Based on analyzed results of treatment with BFA in $S$. cymosum zygotes, we can conclude that the Golgi bodies are responsible for the production and secretion of molecules related to the formation of cell wall membrane, the formation to polarization, cell growth, and orientation of physodes. BFA treated resulted in the loss of organization of Golgi bodies, in turn leading to the formation of vesicles and fusion of physodes. The fused physodes occupied much of the cytoplasm, preventing other cytoplasmic processes, thus directly affecting the development of this alga.

\section{Acknowledgements}

The authors would like to thank the staff of the Electron Microscopy Center Laboratory (LCME), Federal University of Santa Catarina, Florianópolis, Santa Catarina, Brazil, for the use of their transmission electron and confocal microscopes. This study was supported in part by the Higher Education Personnel Improvement Coordination (CAPES, Brazil).

\section{Conflicts of Interest}

The authors declare no conflicts of interest regarding the publication of this paper.

\section{References}

[1] Velozo, A.P.A. and Széchy, M.T.M. (2008) Variações espaciais e temporais no desenvolvimento vegetativo e reprodutivo da macroalga Sargassum C. Agardh (Fucales, Phaeophyceae)—síntese do conhecimento. Oecologia Brasiliensis, 12, 275-290. https://doi.org/10.4257/oeco.2008.1202.09

[2] Riviera, M. and Scrosati, R. (2006) Population Dynamics of Sargassum lapazeanum (Fucales, Phaeophyta) from the Gulf of California, Mexico. Phycologia, 45, 178-189. https://doi.org/10.2216/05-47.1

[3] Széchy, M.T.M. and Paula, É.J. (2000) Padrões estruturais quantitativos de bancos de Sargassum (Phaeophyta, Fucales) do litoral dos estados do Rio de Janeiro e São Paulo, Brasil. Revista Brasileira de Botânica, 23, 121-132. https://doi.org/10.1590/S0100-84042000000200002

[4] Deysher, L. and Norton, T.A. (1982) Dispersal and Colonization of Sargassum muticum (Yendo) Fensholt. Journal of Experimental Marine Biology and Ecology, 56, 179-195. https://doi.org/10.1016/0022-0981(81)90188-X

[5] Coimbra, C. (2006) Inferências filogenéticas na ordem Fucales (Phaeophyceae), com ênfase no gênero Sargassum C. Agardh do Atlântico Sul. Doctoral Thesis, Institute of Biosciences, University of São Paulo, Department of Botany, São Paulo. 
[6] Horvitz, H.R. and Herskowitz, I. (1992) Mechanisms of Asymmetric Cell Division: Two Bs or Not Two Bs, That Is the Question. Cell, 68, 237-255. https://doi.org/10.1016/0092-8674(92)90468-R

[7] Guo, S. and Kemphues, K.J. (1996) A Non-Muscle Myosin Required for Embryonic Polarity in Caenorhabditis elegans. Nature, 382, 455-458. https://doi.org/10.1038/382455a0

[8] Mayer, U., Buttner, G. and Jurgens, G. (1993) Apical-Basal Pattern Formation in the Arabidopsis embryo: Studies on the Role of the Gnom Gene. Development, 117, 149-162.

[9] Wang, Q., Kong, L., Hao, H., Wang, X., Lin, J. and Baluska, F. (2005) Effects of Brefeldin A on Pollen Germination and Tube Growth. Antagonistic Effects on Endocytosis and Secretion. Plant Physiology, 139, 1692-1703. https://doi.org/10.1104/pp.105.069765

[10] Belanger, K.D. and Quatrano, R.S. (2000) Polarity: The Role of Localized Secretion. Current Opinion in Plant Biology, 3, 67-72. https://doi.org/10.1016/S1369-5266(99)00043-6

[11] Kropf, D.L., Bisgrove, S.R. and Hable, W.E. (1999) Establishing a Growth Axis in Fucoid Algae. Trends in Plant Science, 4, 490-494. https://doi.org/10.1016/S1360-1385(99)01509-5

[12] Fowler, J.E. (2000) Cell Polarity in Algae and Vascular Plants. In: Frontiers in Molecular Biology, Oxford University Press, New York, 141-180.

[13] Brownlee, C., Bouget, F.Y. and Corellou, F. (2001) Choosing Sides: Establishment of Polarity in Zygotes of Fucoid Algae. Seminars in Cell and Developmental Biology, 12, 345-351. https://doi.org/10.1006/scdb.2001.0262

[14] Hable, W.E., Miller, N.R. and Kropf, D.L. (2003) Polarity Establishment Requires Dynamic Actin in Fucoid Zygotes. Protoplasma, 221, 193-204. https://doi.org/10.1007/s00709-002-0081-0

[15] Alessa, L. and Kropf, D.L. (1999) F-Actin Marks the Rhizoid Pole in Living Pelvetia compressa Zygotes. Development, 126, 201-209.

[16] Shaw, S.L. and Quatrano, R.S. (1996) The Role of Targeted Secretion in the Establishment of Cell Polarity and the Orientation of the Division Plane in Fucus Zygotes. Development, 122, 2623-2630.

[17] Berger, F., Taylor, A. and Brownlee, C. (1994) Cell Fate Determination by the Cell Wall in Early Fucus Development. Science, 263, 1421-1423. https://doi.org/10.1126/science.263.5152.1421

[18] Viotti, C., Bubeck, J., Stierhof, Y.D., Krebs, M., Langhans, M., et al. (2010) Endocytic and Secretory Traffic in Arabidopsis Merge in the Trans-Golgi Network/Early Endosome, an Independent and Highly Dynamic Organelle. Plant Cell, 22, 1344-1357. https://doi.org/10.1105/tpc.109.072637

[19] Ito, Y., Toyooka, K., Fujimoto, M., Ueda, T., Uemura, T. and Nakano, A. (2017) The Trans-Golgi Network and the Golgi Stacks Behave Independently during Regeneration after Brefeldin: A Treatment in Tobacco BY-2 Cells. Plant and Cell Physiology, 58, 811-821. https://doi.org/10.1093/pcp/pcx028

[20] Robinson, D.G., Brandizzi, F., Hawes, C. and Nakano, A. (2015) Vesicles versus Tubes: Is Endoplasmic Reticulum-Golgi Transport in Plants Fundamentally Different from Other Eukaryotes? Plant Physiology, 168, 393-406. https://doi.org/10.1104/pp.15.00124

[21] Drupee, P. and Sherrier, D.J. (1998) The Plant Golgi Apparatus. Biochimica et Bio- 
physica Acta, 1404, 259-270. https://doi.org/10.1016/S0167-4889(98)00061-5

[22] Keidan, M., Friedlander, M. and Arad, S.M. (2009) Effect of Brefeldin A on Cell Wall Polysaccharide Production in the Red Microalga Porphyridium sp. (Rhodophyta) through Its Effect on the Golgi Bodies. Journal of Applied Phycology, 21, 707-717. https://doi.org/10.1007/s10811-009-9406-0

[23] Callow, M.E., Crawford, S., Wetherbee, R., Taylor, K., Finlay, J.A. and Callow, J.A. (2001) Brefeldin A Affects Adhesion of Zoospores of the Green Alga Enteromorpha. Journal of Experimental Botany, 52, 1409-1415. https://doi.org/10.1093/jexbot/52.360.1409

[24] Tsekos, I., Orologas, N. and Dimopoulou, A. (2007) Effect of Brefeldin A on the Structure and Function of the Golgi Bodies in the Marine Red Algae. Journal of Biological Research, 7, 29-39.

[25] Hadley, R., Hable, W.E. and Kropf, D.L. (2006) Polarization of the Endomembrane System Is an Early Event in Fucoid Zygotes Development. BMC Plant Biology, 6, Article No. 5. https://doi.org/10.1186/1471-2229-6-5

[26] Nebenfuhr, A., Ritzenthaler, C. and Robinson, D.G. (2002) Brefeldin A: Deciphering an Enigmatic Inhibitor of Secretion. Plant Physiology, 130, 1102-1108.

https://doi.org/10.1104/pp.011569

[27] Geldner, N., Friml, J., Stierhof, Y.D., Jurgens, G. and Palme, K. (2001) Auxin Transport Inhibitors Block PIN1 Cycling and Vesicle Trafficking. Nature, 413, 425-428. https://doi.org/10.1038/35096571

[28] Richter, S., Voß, U. and Jurgens, G. (2009) Post-Golgi Traffic in Plants. Traffic, 10, 819-828. https://doi.org/10.1111/j.1600-0854.2009.00916.x

[29] Simioni, C., Rover, T., Schmidt, E.C., et al. (2014) Effects of Brefeldin A on the Endomembrane System and Germ Tube Formation of the Tetraspore of Gelidium floridanum (Rhodophyta, Florideophyceae). Journal of Phycology, 50, 577-587. https://doi.org/10.1111/jpy.12187

[30] Bisgrove, S.R., Henderson, D.C. and Kropf, D.L. (2003) Asymmetric Division in Fucoid Zygotes in Positioned by Telophase Nuclei. The Plant Cell, 15, 854-862. https://doi.org/10.1105/tpc.009415

[31] Zitta, C.S., Rover, T., Hayashi, L. and Bouzon, Z.L. (2013) Callus Ontogeny of the Kappaphycus alvarezii (Rhodophyta, Gigartinales) Brown Tetrasporophyte Strain. Journal of Applied Phycology, 25, 615-629. https://doi.org/10.1007/s10811-012-9896-Z

[32] Bouzon, Z.L., Ouriques, L.C. and Oliveira, E.C. (2006) Spore Adhesion and Cell Wall Formation in Gelidium floridanum (Rhodophyta, Gelidiales). Journal of Applied Phycology, 18, 287-294. https://doi.org/10.1007/s10811-006-9028-8

[33] Hable, W.E. and Hart, P.E. (2010) Signaling Mechanisms in the Establishment of Plant and Fucoid Algal Polarity. Molecular Reproduction and Development, 77, 751-758. https://doi.org/10.1002/mrd.21199

[34] Yan, X. and Zhang, J. (2014) Embryology of Zygote and Development of Germling in Sargassum vachellianum Greville (Fucales, Phaeophyta). Journal of Applied Phycology, 26, 577-585. https://doi.org/10.1007/s10811-013-0102-8

[35] Hable, W.E. and Kropf, D.L. (1998) Roles of Secretion and the Cytoskeleton in Cell Adhesion and Polarity Establishment in Pelvetia compressa Zygotes. Developmental Biology, 198, 45-56. https://doi.org/10.1016/S0012-1606(98)80028-6

[36] Fowler, J.E. and Quatrano, R.S. (1995) Cell Polarity, Asymmetric Division, and Cell Fate Determination in Brown Algal Zygotes. DDevelopmental Biology, 6, 347-358. 
https://doi.org/10.1016/S1044-5781(06)80076-9

[37] Fowler, J.E. and Quatrano, R.S. (1997) Plant Cell Morphogenesis: Plasma Membrane Interactions with the Cytoskeleton and Cell Wall. $\gg$ Annual Review of Cell and Developmental Biology, 13, 697-743. https://doi.org/10.1146/annurev.cellbio.13.1.697

[38] Capitano, G., Baldan, B., Filippini, F., Terzi, M., Loschiavo, F. and Mariani, P. (1997) Morphogenetic Effects of Brefeldin A on Embryogenic Cell Cultures of Daucus carota L. Planta, 203, 121-128. https://doi.org/10.1007/s00050172

[39] Henderson, J., Satiat-Jeunemaitre, B., Napier, R. and Hawes, C. (1994) Brefeldin A-Induced Disassembly of the Golgi Bodies Is Followed by Disruption of the Endoplasmic Reticulum in Plant Cells. Journal of Experimental Botany, 45, 1347-1351. https://doi.org/10.1093/jxb/45.10.1347

[40] Donaldson, J.G., Finazzi, D. and Klausner, R.D. (1992) Brefeldin A Inhibits Golgi Membrane-Catalysed Exchange of Guanine Nucleotide onto ARF Protein. Nature, 360, 350-352. https://doi.org/10.1038/360350a0

[41] Donaldson, J.G. and Klausner, R.D. (1994) ARF: A Key Regulatory Switch in Membrane Traffic and Organelle. Current Opinion in Cell Biology, 6, 527-532. https://doi.org/10.1016/0955-0674(94)90072-8

[42] Langhans, M., Forster, S., Helmchen, G. and Robinson, D.G. (2011) Differential Effects of the Brefeldin A Analogue (6R)-Hydroxy-BFA in Tobacco and Arabidopsis. Journal of Experimental Botany, 62, 2949-2957. https://doi.org/10.1093/jxb/err007

[43] Schoenwaelder, M.E.A. (2002) The Occurrence and Cellular Significance of Physodes in Brown Algae. Phycologia, 41, 125-139. https://doi.org/10.2216/i0031-8884-41-2-125.1

[44] Bisgrove, S.R. and Kropf, D.L. (2007) Asymmetric Cell Divisions: Zygotes of Fucoid Algae as a Model System. Plant Cell Monographs, 9, 323-341.

https://doi.org/10.1007/7089_2007_134 